\title{
Fake Prophets and Evangile for Sale in Amma Darko's Not without Flowers
}

\author{
Koumagnon A. Djossou Agboadannon ${ }^{1}$, Ashani Michel Dossoumou ${ }^{2 *}$ \\ ${ }^{1}$ Laboratoire du Groupe de Recherche sur l'Afrique et la Diaspora (GRAD), University of Abomey-Calavi \\ (UAC), BENIN
}

2Lecturer researcher of Applied English Linguistics, Laboratory for Research in Linguistics and Literature (LabReLL), Faculty of Letters, Languages, Arts and Communications (FLLAC), University of Abomey-Calavi $(U A C), B E N I N$

\begin{abstract}
*Corresponding Author: Ashani Michel Dossoumou, Lecturer researcher of Applied English Linguistics, Laboratory for Research in Linguistics and Literature (LabReLL), Faculty of Letters, Languages, Arts and Communications (FLLAC), University of Abomey-Calavi (UAC), BENIN
\end{abstract}

\begin{abstract}
In the postcolonial period, Africa has inherited many socio-economic changes including Christianity and its by-products. Christianity was introduced to "brainwash" Africans to no longer resist colonization as well as to put an end to ancient pagan practices. Christianity's armed wing is evangelization. Unfortunately, some hungry and brash people in search for money, power, greatness and majesty hijacked evangelization's aim. Today, this form of evangelism is prevailing in the smallest and the most remote corners in all African urban centers. It is alive, vivid, violent, electrifying and demanding. It acts to "win" lost souls for Christ, the Savior. Evangelization in the postcolonial Africa claims to work miracles and wants appeal to the poor and left-aside; however bilks them of their properties and promises them spiritual prosperity and heaven. In this article, I give my insights on the position of a contemporary African writer addressing this scourge in her own way and words. Amma Darko bluntly denounces this practice of "new prophets". She spares no detail to disclose these so-called new prophets' modus operandi. Finally, I show the unfortunate consequences on those who blindly believe in these prophets.
\end{abstract}

Keywords: Colonization, Fake Prophets, Gospel, Evangelization, Christianity, Morality, Offerings.

\section{INTRODUCTION}

With her novel Not Without Flowers, (year) Amma Darko has had the merit to investigate and give us the clues on the strong resurgence and proliferation of prophetic or fascinating religious movements particularly in contemporary Africa in her novel. This paper draws on knowledge inspired by biblical theories on prophets, miracles and profits to suggest the direction that Darko's assessment may take. In this sense, this paper considers the sociological approach as backbone for its analysis. Ushie (2008, 6) submits that "Literature must serve society by steeping itself in politics, by intervention, and writers must not merely write to amuse or to take a bemused, critical look at society. They must play an interventionist role". However, I am watchful not to 'venture where angels are afraid to tread', because there's sometimes a danger of attempting to judge spiritual matters using rationale and logic. In Not Without Flowers, Amma Darko highlights the prophets' mindset morality in Ghanaian cities and by iteration to all other African urban centres.

This phenomenon of "new prophets" is a poverty-related social predicament. The "New prophets" sprout, spread and proliferate along with crisis outbreak in the country. They mushroom like vegetables in the rainy season and come in cities with many famous biblical references such as Moses, Joshua, Elijah, Elisha, Jeremiah, Isaiah, Zechariah or Abednego. The so-called "men of God" go to markets, radio stations, television, hospitals and other public places, distribute flyers in buses and in cars to communicate with the population. They gather people through movies and evangelize them. They try to persuade people by all means to believe them. Their strategies are used to gain followers for their weekly masses and then use these followers as their own machine of fortune.

The Nigerian satirist and drama writer Wole Soyinka had already denounced it in his The Trials of Brother Jero in 1964. In this play, Soyinka portrays Brother Jeroboam as a self-proclaimed prophet 
evangelizing by the beach of unnamed town to attract followers. Soyinka uses Brother Jero to accomplish his task of satirizing the commercialization of the Christian faith just a little time after independence. Jero or Jeroboam uses evangelism as his way out of poverty and misery. This phenomenon is to be feared and publicly addressed. To these new prophets, any sickness or life situation has its understanding in supernatural. Then, lures the idea of prayer camp creation to receive people in need of spiritual services because for instance "the plight of mental patients" shall see its diagnosis and its end as Amma Darko portrays in a "Whipping to Conquer Satan's camp"; a camp which name its owners hide purposely into "We Conquer Satan." (Darko, )

Amma Darko uses many instances to portray Ghanaian contemporary society. In Not Without Flowers, Darko illustrates that these "men of God», to have clients for their spiritual centres "employ people who do a wonderful public relations job for them all over. Some operate around the psychiatric hospitals and target visitors seen to be well-to-do. They adopt all kinds of ways to convince these people that they are wasting their time and money at hospital and recommend them the camp." (Darko, )

Darko lets the readers know that pastors put into the minds of their listeners that "mental illness means possession by evil spirits" because "cursed is the man who does not uphold the words of this law carrying them out." Then, by vivid, hot and hard prayers, they must spiritually check their victims' family history, the member who had not upheld this word in order to expel the sin properly.

In this context, to be a mental patient or to fail to procreate is forbidden in contemporary Ghana. Darko's description of these patients' asylum stays showcases the tortures they underwent to expel the causative spirits and to healing them:

No pillow for her head...about sixty, skeletal features, completely bald...Around each of her ankles was an iron ring hanged to a thick chain. It was hooked through a hole in a huge blunt iron rod buried halfway into the concrete floor in the centre of the hut. There were other metal hooks in the hole from the other chained ankles. No wonder the wooden door was never locked.

There was no need to. The frail woman stank of stale urine (Darko, .

These lines strengthen my argument that the ills in African society are being purged and perhaps healed through the knowledge of their causes and their devastating consequences. Among the causes of this social plight, we have colonization, poverty, misery, and unemployment, and government lack of control.

\section{WHO IS AMMA DARKO?}

It is significantly to note that "Ophelia Amma Darko was born in 1956, a year before Ghanaian independence, in Ghana's Northern region". She was a Saturday-born which confers her the name Amma. The name Ophelia that she never mentions is a Christian name, maybe because of her being early discouraged by the implication of the Christian Church in the demolition of her country's culture. At that time of her birth, West African countries' political leaders being at the top of their ideological struggle for independence did not accept any family to give European (Christian) names to their children: it was the period of 'African Conscientiousness Awareness' and 'Pan-Africanism'. In Ghana, children carry automatically their father's name, but the lineage is matrilineal. Amma Darko is a member of a renowned Fanti ethnic group. Fanti is the dominant tribe in the Central Region of Ghana where most of Ghana's historical slave castles and forts can be found. In the past, the "Fanti state occupied the coastal belt of Ghana, from Prah in the West to about twenty-four kilometres west of Accra, the current capital of Ghana. The Fanti states included the Eguafo, Dena (Elmina), the Efutu, Asebu, the Etsii, Komenda and Shama. The Fanti controlled well-established kingdoms on the coast by the beginning of the fifteenth century"2.

Amma Darko was one of the seven children in her family and was raised by her aunt and uncle, a hospital pharmacist. She succeeded in all her secondary school final exams and went to Kwame Nkrumah University of Science and Technology (KNUST) in Kumasi. Unlike Ama Ata Aidoo, she

\footnotetext{
${ }^{1}$ Zak, Allen Louise. (2007). "Amma Darko: Writing Her Way, Creating a Writing Life" Ed. Vincent O. Odamtten, Broadening the Horizon: Critical Introductions to Amma Darko. London: Ayebia Clarke Publishing, Print., p. 12.

${ }^{2}$ http://www.ghanaweb.com/GhanaHomePage/tribes/fanti.php
} 
did not study Creative Writing, but Industrial Design. She was once involved in student drama theatricals. Amma Darko is married, lives with her husband and children. The typical family in which she lives is that of her female character Kabria in $F L$. When she graduated from the University in 1980, she tried like all Ghanaian modern educated students at the time to emigrate to Europe (Germany) in "search for job opportunities because of the political, economic and social woes"3 amplified by repeated military coups. The economic situation in Ghana was so dismal that many of her compatriots left the country to seek a place 'beyond the horizon'. The Ghanaian government of the time had also instituted strict measures to comply with the International Monetary Fund's requirements for economic restructuring. People were living wretchedly, so flee from that hell-like atmosphere was their sole wish and Amma Darko was among them. The author confesses later this "Home was suffocating me." Thinking that Europe would be that imagined heaven described by the been-tos, she was confronted to the same joblessness and was confined to bleak jobs such as housemaid to survive and also send money to her parents. She discovered that her female compatriots who succeeded in sending money home were those involved in sex business, prostitution or fell in the hands of African transnational sexual traffickers' networks. All this inspires Amma Darko in writing her first novel Beyond the Horizon. However, more profoundly during her childhood, Amma Darko might have listened to a series of Ghanaian tales on the Slave Trade, stories of intrepid Queen Warriors in Fanti region. She might have read some historical books, novels, dramas. Her coming on the literary stage in 1991 was welcomed by many people as the poet and critic Kofi Anyidoho, noted in his introductory essay to Amma Darko's third published novel, Faceless:

Students and scholars of African Literature who, like me, have often wondered about the apparent absence of any major female Ghanaian writers following the remarkable pioneering work of Efua T. Sutherland and Ama Ata Aidoo, can now rest assured that a worthy successor has emerged in the person of Amma Darko. ${ }^{5}$

In fact and for real, Amma Darko might have loved and been personally inspired by the historical and brave words of Queen Mother Yaa Asantewaa, the Gatekeeper of the Golden Stool while the famous Ashanti Empire was about to fall in the hands of British colonizers in 1896, who declared the following:

Now I have seen that some of you fear to go forward to fight for our King.

If it were in the brave days of Osei Tutu, Okomfo Anokye, and Opolu Ware, leaders would not sit down to see their King taken away without firing a shot. No white man could have dared to speak to a leader of the Ashanti in the way the Governor spoke to you this morning. Is it true that the bravery of the Ashanti is no more? I cannot believe it. It cannot be! I must say this, if you the men of Ashanti will not go forward, then we will. We the women will. I shall call upon my fellow women. We will fight the white men. We will fight till the last of us falls in the battlefields. ${ }^{6}$

The above passage is the word of a female 'general of army' talking to the troops before waging the last fight to defend her kingdom, her dignity which she felt duty-bound to defend to the last second of her life. Honorable Naa Yaa Asantewaa reminds her people how conquerors, brave and daring were women in the past. When Amma Darko writes her own way about the Ghanaian women, all the previous readings might have revolved around in her mind. But it was only when she travelled to Germany, after having obtained a degree from the College of Arts with a minor in English that she realized that she could write about the daily life of black Africans 'beyond the horizon'. In this vein, Odamtten confirms:

\footnotetext{
3 Source: Commission of the European Communities: Eurostat, Netherlands Interdisciplinary Demographic Institute (NIDI). 2001. Push and Pull Factors Determining International Migration Flows, "Why and Where: Motives and Destinations."

${ }^{4}$ Zak, Allen Louise (2007). "Amma Darko: Writing Her Way, Creating a Writing Life" (Ed.) Vincent O. Odamtten, Broadening the Horizon: Critical Introductions to Amma Darko. UK/London: Ayebia Clarke Publishing, Print., p. 12.

5 Zak, Allen Louise (2007). “Amma Darko: Writing Her Way, Creating a Writing Life” Ed. Vincent O. Odamtten, Broadening the Horizon: Critical Introductions to Amma Darko. London: Ayebia Clarke Publishing, Print, p. 4.

${ }^{6} \mathrm{http} / / / \mathrm{www}$. blackhistoryheroes.com/2010/05/queen-mother-nana-yaa-asantewaa.html
} 
What she and many others found was a life of menial jobs in order to survive and maintain some modicum of dignity. She was able to carve out the space and time from which she could write the kind of narrative about the sort of people she knew and met. Unlike her literary predecessors, who often wrote about individuals torn by the contradictions of negotiating the highways and byways of tradition and modernity [...], Darko rejected such self-absorbed characters.7

In a conversation shared years ago, Amma Darko was sure of this "I harbour an unflinching conviction that I am filling a void with the stories I tell. I have faith and confidence in myself about my art. My love for my stories entrenches that." ${ }^{8}$ In Ghana, when talking about literary matriarchs, Ama Ata Aidoo is considered as the mother of Ghanaian literature, and as someone who paved the way for many female writers who came after her so important is the link between both. Amma Darko is one of the youngest members of the third generation like the Nigerian Chimamanda Ngozi Adichie. The academics and critics Pius Adesanmi and Chris Dunton discuss the third generation in their essay "Nigeria's Third Generation Writing: Historiography and Preliminary Theoretical Considerations." Some of the important differences between the first and second generation are, firstly, the shift from poetry to the fiction and, secondly, the recognition its output received from the international community." Some of the important thematic features of the third generation's fiction include an urban setting. The thematic also emphasizes "deprivation, the denial of individual human rights and aspirations, the degradation of social relations under a series of increasingly despotic and corrupt regimes" experiences of ordinary people, not the ones who won scholarship to go abroad, not the ones whose journey to Europe could be described as a Season of Migration to the North, the ones who were too poor or unfortunate to know anything other than what society made apparent" (Broadening, 2007: 5).

In Kofi Anyidoho's "Introductory Essay", he describes Amma Darko as a major female Ghanaian writer whose works are akin to the likes of Efua T. Sutherland and Ama Ata Aidoo. Both her first and second novels, Beyond the Horizon and The Housemaid, focus on the plight of women and young girls in a merciless world dominated by greedy, irresponsible, sexual predators; dangerous and pitiless street masters like Akobi, Osey, Pompey, Poison and Macho. Faceless adds up to the other two novels to form what Anyidoho calls "an important trilogy." "The style strategy by which Amma Darko writes her novels is of quality and serves to temper her unflinching presentation of stark circumstances and human suffering. Her depiction of social situation makes non-existent the border between fiction and fact. For instance, the narrative about Sodom and Gomorrah in Faceless seems so authentic that one seems to meet imaginatively at every corner of the slum in Accra Fofo and her friends. Furthermore, Bible readers who know the story of Sodom and Gomorrah can image the helllike life in there before its allegorical destruction and can doom the future of its habitants.

As for Lewis Nkosi (Nkosi, 1981:102) feels that the "passion to make the feature of personal experience a governing emotion" 12 may result in becoming "a compulsive disposition" in the works of any writer, especially in those of a so-called "protest" writer. In consequence, he justifies the inclusion of personal details in a novel only when it serves as an incentive to artistic creation. Just like Bessie Head ${ }^{13}$ used allegories in most of her writings, Amma Darko wants us to decode her urging message and the extent to which the use of the biblical allegories are necessary.

\footnotetext{
7 Odamtten, Vincent O. (2007) "Introduction: Beyond the Comfort Zone" (Ed.) Vincent O. Odamtten, Broadening the Horizon: Critical Introductions to Amma Darko. London: Ayebia Clarke Publishing, Print., p. 5. ${ }^{8}$ Idem.,

9 Adesanmi, Pius \& Chris Dunton (2005). "Nigeria's Third Generation Writing: Historiography and Preliminary Theoretical Considerations", English in Africa, 1, 32.

10 Adesanmi, Pius \& Chris Dunton (2005). "Nigeria's Third Generation Writing: Historiography and Preliminary Theoretical Considerations", English in Africa: 1-32, p. 8.

11 Anyidoho, Kofi (2010). Amma Darko's Faceless: A New Landmark in Ghanaian Fiction, an Introductory Essay, (ed.) Sub-Saharan Publishers, p. ix.

12 Nkosi, Lewis (1981). Tasks and Masks: Themes and Styles of African Literature. Essex: Longman.

${ }^{13}$ Bessie Amelia Head was born on July 6, 1937 in Pietermaritzburg, Natal (South Africa). Bessie Amelia Head was the daughter of a white woman and black man. In 1961, Bessie met Harold Head. Bessie published When Rain Cloud Gather in 1968, Maru in 1971 and A Question of Power in 1973. She died from hepatitis on April 17, 1986, at the age of 48. Posthumously, the novel The Cardinals was published in 1993. In both her fiction
} 
Amma Darko later confirms the good therapeutic utility of humour and orality in African narratives: "Humour is strength. The ability to laugh at one's self and crack jokes at one's own expense is a healthy balm for the soul. Our Ananse stories are full of humour even when the subject matter is suffering and death" ${ }^{\prime 4}$. The Kweku Ananse character Amma Darko is talking about is a spider with human characteristics. His eight limbs are often depicted as four arms and four legs. His special relationship with the Creator goes back to the time of creation. He is wise and cunning and a trickster. Every Kweku Ananse tale bears some subtle advice and words of wisdom. Told and retold by the captives from the Ashanti tribe during the Trans Atlantic Slave Trade, the Kweku Ananse stories spread to other parts of the world. They have evolved in places like the southern parts of the USA; the West Indies and the Caribbean.

\section{IMPACT OF COLONIZATION AND EVANGELISM IN AFRICA}

Societies that have been colonized are negatively affected in many ways, most important of which is the erosion of their cultural values. Laurie F. Maffly-Kipp in her An Introduction to the Church in the Southern Black Community explained:

By 1810 , the slave trade to the United States had come to an end and the slave population began to increase naturally, giving rise to an increasingly large native-born population of African Americans. With fewer migrants who had experienced Africa personally, these transformations allowed the myriad cultures and language groups of enslaved Africans to blend together, making way for the preservation and transmission of religious practices that were increasingly "African-American. This transition coincided with the period of intense religious revivalism known as "awakenings. ${ }^{15}$

In the case of Africa, colonization also called the "Scramble for Africa "means the invasion, occupation, and annexation of African territory by European powers during the period of New Imperialism, between 1881 and 1914. According to Juhani Koponen in The Partition of Africa: A Scramble for a Mirage?, all the European forces "agree that the partition was an extraordinary surge of European imperialism. In no more than two decades at the end of the nineteenth century, European powers expanded out from the few strongholds they had along the African coastlines and divided the vast mass of the continent between them."

Indeed, the colonization of African continent has begun with Evangilization, Gospel and Christianity teaching. The first missionary priests and pastors who set their feet in Africa have come along with some attractive social and educational program. The main target is to rape Africa's culture, extract clandestinely her agricultural, intellectual and mineral resources, dismantle her traditional beliefs and cultural rites ascribed to evil devil and to hostage-take her natural and agrarian endowments. But instead of a direct modus operandi, colonial masters have put forth education and Evangelization. Before leaving Europe, the then various King, namely King Leopold II, in 1883 has gathered the "Men of God, Padre, Pastor, Father, Père" as Africans indigenous population used to referring to them, to brief them on the real essence of their delicate mission which has nothing to do with teaching Africans about goodness and God, because they know God. The major themes assigned to the missionaries to inculcate and grave in the mind of Africans was, inter alia, poverty (as only the poor can see the kingdom of God). Meanwhile, they would be enriching themselves, dining, wining and enjoying, while Africans would be encouraged to go about fasting if they want to see the kingdom of God. Among those missionaries, are professionals linguists, architects, geologists, pharmacologists, chemists, surveyors and sociologists, etc,... whose objectives were to explore Africa's land, soil, mind, ecological and underground resources and come back to Europe with well written reports including mostly the geological, ecological and mineral maps of the area covered during their mission,. All this has paved the way for a smooth (even though there were some sporadic resistance

and the autobiographical accounts within her letters, Head returns again and again to a narrative about the illicit union between a socially superior mother and a subordinate father, the mother's trauma after being made to relinquish her child, and the daughter's rejection by her mother's family and stigmatization by society.

${ }^{14}$ Broadening the Horizon, idem

${ }^{15}$ Maffly-Kipp, Laurie F. (2001). An Introduction to the Church in the Southern Black Community. Illinois Press.

${ }^{16}$ Juhani Koponen. (1993). The Partition of Africa: A Scramble for a Mirage? Ed, Nordic Journal of African Studies 2(1): 117-135. 
movements sooner or later subdued by the invaders) colonization and theft of Africa's resources including its beliefs, cultures and traditions.

Despite all these, there is education which appears to be more or less one of the lopsided benefit of Africa (as it does not take into account the African realities, rather, it throws away everything endogenous and bleached the mind of African leaners, ridding them off any of their ancestral, cultural and traditional ways of doing things). While ignoring Africa's societal realities, some westerners still following the editorial lines of their colonizing move and mind have attempted to produce uninformed writings on Africa' history, culture, beliefs and tradition. Those writings are packed with forged and, to a larger extent fabricated, misconstrued and misinterpreted realities of African people. Of course, Education has opened and sharp-eyed the first African intellectuals to write rejoinders and true criticism on colonization through their works.

Writings by Europeans like Joseph Conrad's Heart of Darkness showed views of individuals determined "to look at Africa through their cultural prisms and conclude that Africans were backward and uncivilized". The story portrayed in Heart of Darkness explores the historical period of colonialism in Africa to exemplify Marlow's struggles. Marlow, like other Europeans of his time, was brought up to believe that Africans are filthy, stinking beings and dark soul and body. He tells of a journey down the Congo River in the 1890s: "We were wanderers on a prehistoric earth, on the earth that wore the aspect of an unknown planet. We could have fancied ourselves the first men taking possession of an accursed inheritance."

Here is Conrad's description of an African who looked after the boiler on the riverboat: "And between whiles I had to look after the savage who was fireman. He was an improved specimen; he could fire up a vertical boiler. He was there below me, and, upon my word, to look at him was as edifying as seeing a dog in a parody of breeches and a feather hat, walking on his hind legs."

Colonialism was seen as the white men's mission to help civilize and improve a savage, cannibal and dark race. They felt therefore that colonization and evangelization were white men's right and that they had the heavenly mission to "civilize" Africans. Converting Africans to Christianity was one of the ways through which Europeans enacted their civilizing mission though the exact link between colonialism and Christianity is unclear.

Historians do not agree on what the relationship between Christian missionary activity and colonialism was. Evidence suggests that while many missionaries opposed the harsher aspects of colonialism, they were supportive of the colonization of African countries. Missionaries who supported colonialism believed that European control would provide a political environment that would facilitate missionary activity in Africa. The other reason of their support was that God ordained Europeans to conquest free lands in Africa to bring light and civilization to "darkness" and "ignorance".

Christianity was introduced to Africa in the same period as colonisation. According to Kwame Bediako's Theology and Identity: Impact of Culture upon Christian Thought in the Second Century and in Modern Africa ((1999) :

The contemporary African Christian identity problem derives not just from the fact of conversion to Christianity from traditional religion, but also from the whole impact of the West on Africa. This, he argues, began well before the arrival of missionaries, particularly with the slave trade which shaped negative European attitudes to and stereotypes of Africa. Christian missionary activity began in earnest in the 19th century during the same period of time that European countries were becoming more engaged in Africa. This support for colonialism played an important role in legitimizing the colonial endeavour among the citizens of the colonizing powers in Europe. ${ }^{17}$

One of the famous quotations linking the downsides of evangelism to colonisation is that of Mzee Jomo Kenyatta, the first president of Kenya. He states "When the Missionaries arrived, the Africans had the land and the Missionaries had the Bible. They taught how to pray with our eyes closed. When we opened them, they had the land and we had the Bible." This quotation shows the strategy

\footnotetext{
${ }^{17}$ Bediako, K. (1999). Theology and Identity: Theology and Identity: Impact of Culture upon Christian Thought in the Second Century and in Modern Africa. Regnum Books, 507pp, ISBN: 187034510X.
} 
colonizers used to take lands from Africans. At that time missionaries were a pair working hand with colonizers, so acting like wolves in sheep's clothing.

After the legacy of slave trade, colonization not only left Africa in poverty, but also left other tough traumas related to evangelism. My concern is not about slavery but evangelism and fake prophets.

\section{FAKe Prophets AND Profits: Modus OPERANDI}

Before I highlight evangelical pastors' common methods of tracking, attacking and convincing their victims to join prayers camps, to give offerings and tithe. I will show the description Darko gives in her fiction about this growing phenomenon. Darko pinpoints the characteristics of dubious men of God by writing this: "An enigmatic man of God, Prophet Abednego, he calls himself, goes repeatedly after a radio presenter, Sylv Po, to help him reach a man who has been attacked in one leg, by the devil. Who is this Man of God and what is his motive?" Darko give us all that we are in need of. Darko describes:

He was tall and lean, with a slight hunchback and he was wearing a long white robe reaching to the ground. Across his waist, the ends of a bright red sash, tied loosely on the left, hung about a foot above the edge of the robe. His feet were bare. He reached the gate, walked up to the guard and faced him, almost halting at attention. "I have been sent by God to a man here called Sylv Po!" He announced. My name is Prophet Zechariah Abednego. (Darko, 136-9)

Who is the man? The mysterious man's name was Kofi Poku at birth, and then called himself "Raja Hey, alias Who Killed Lucy, alias Pardon Me, alias Forever Young" as soon as he set foot in Accra. But when he received the call of God after his friend's mysterious death and having been alone and dead sacred for a long time in the street, he changed all these pagan names to Prophet Abednego or Prophet Zechariah Abednego. But it is worth to say that Kofi Poku was a young man who left his village like many young men in quest for job and driven by their lust to make fast money in growing urban centres like Accra. This youth exile also called exodus is nowadays very frequent not only in Ghana but also in other African countries. Jobless in their villages and having been told of the ways people get money "easily" in cities, these young men bid farewell to their parents.

Darko highlights how Agyei Poku's alias Cityman convinced his friend Kofi Poku as if as soon as they got to Accra, thousands over thousands of bags full of Ghanaian money were waiting for them somewhere in a corner and left by someone tired to keep in his house. Consequently, Cityman "cooks" his friend, so that he believes a committee of people is waiting to welcome them and give them a store of items to sell and then assign them "the street from 37 Military Hospital to the Airport traffic lights. (Darko, 237)" Unfortunately, the crude and rude reality when Kofi Poku came in Accra "was a loiter day in day out around the Accra railway station hoping and praying for something to happen. Then one day something happened" (Darko, 237)

What happened that day determined Kofi Poku's future name and Amma Darko goes on clarifying "Unscrupulous pastors of little known churches of dubious shades and colours would come and hire people to go and pretend to be deaf and dumb or blind and receive instant miraculous healing at their church services to swell the members of their congregation. Hustling around the Nkrumah Circle one day he was hired for a specific assignment. Raja took the job and performed excellently."

After having performed excellently his very first job, Raja Hey decided to create his own "business" because he was not paid the full amount of money the entrepreneur promised to give. However, Darko goes beyond and seems to give Raja Hey an opportunity to be close to Preacherman's alias Wahala, a street preacher and expert in delivering electrifying prayers as if the Holy Spirit was at him. He preached around the Rawlings Park. He engaged Raja Hey as his personal assistant "with a main duty of keeping an eagle eye on the collection money people would donate, because some people were really bad. Not only would they not give Preacherman a penny, but would also want to help themselves to what others had given him" (Darko, 242).

Like Ghana, Zimbabwe is also facing this phenomenon. So many are the prophets who arose in the post-independence period in that country so that President Robert Mugabe questioned their integrity at a funeral in November 2012, "...Also in some churches you hear that a husband and his wife are

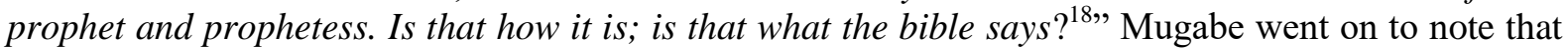

\footnotetext{
${ }^{18}$ Ezra Chitando, Masiiwa Ragies Gunda, Joachim Kügler (Eds.) (2013). Prophets, Profits and Bible in Zimbabwe (BiAS 4), 2nd ed., Bamberg: UBP.
} 
"there seemed to be more prophets in Zimbabwe than the ordinary people" $"$. This is not a joke, but the President's point of view was loud, clear and limpid: his nation and even Africa had seen the increase of many prophets and prophetesses led by the same drive. High poverty combined moneygreediness prophets made many Africans so desperate, fearful of witchcraft, sorcery, and evil spirits that they had to seek for divine intervention in urban centres or in villages. Some prophets take advantage of their fear and claim to offer divine solutions to people's problems. They claim to heal every illness, to pray for people to acquire visas, money, houses, cars, wives, babies, job, and the like. These prophets charge a lot of money for their spiritual work. They force their followers to give offerings for them to go to heaven after living very poorly on earth.

This situation is happening nearly in all Africa countries. Wole Soyinka gives everlasting insights into the lucrative evangelism industry. Nowadays, to broad the criticism of this predicament, Nigerian entrepreneur-video film producers and marketers have created a popular art studio called Nollywood just like Hollywood in America. Recently, validating the same decision, Ghanaians have also established Ghallywood. All the day long, movies related to evangelisation either censoring or approving the fact are displayed. Nollyhood and Ghallywood serve simultaneously as entertainment for its enthusiastic public. Through these canals, contemporary African society's existential "despair that defines their individualities, their agonies and the ulcerous spots in their lives are dramatized. That is the realities of their humanhood stare at them screen to face". So, after having carried the heavy burden of slave trade, colonization, Africa has to face poverty, sicknesses, tribal wars, superstitions, immigration, and fake prophecies.

This situation draws the attention of anyone in love with Africa and its values. This leads one of her daughter to react. Darko does not wait for anybody to give her permission to write on that growing phenomenon. She bluntly denounces it in her fiction. In her novel, for example what has captured the imagination and interest of these market women are the electrifying prayers this leading figure, this "Preacherman" delivers. I call it the first modus operandi. The new prophets currently operate in most African urban cities using the same strategy.

The second approach by these people is the gospel of prosperity by asking the followers to leave all their belongings to God reciting every time these biblical passages which declare: "Do not store up riches for yourselves here on earth, where moths and rust destroy, and robbers break in and steal. Instead, store up riches for yourselves in heaven, where moths and rust cannot destroy, and robbers cannot beak in and steal. For your heart will always be where your riches are."Sell all your belongings and give the money to the poor. Provide yourselves purses that don't wear out, and save your riches in heaven, where they will never decrease, because no thief can get to them, and no moth can destroy them. For your heart will always be where your riches are."

Here Darko enters common people's imagination: "Preacherman also never forgot to always remind them the more cash offerings they made, the more the Good Lord would turn his generosity machine to reward them".

Brother Amartey does not condone this kind of lie and openly criticizes this in his work In The Menace Of False Prophets And Pastors In Africa:

They rob and steal from the people. They speak lies and utter vain prophecies and visions, leading people astray. They draw people to themselves, claiming to have a special relationship with God, but they lie and deceive the people. They claim to know everything about you but they lie, and know nothing! They sleep with married women and break the hearts of single women. They destroy homes and families. They destroy marriages, businesses and destinies. They are mere diviners and sorcerers and are no prophets of God at all ${ }^{20}$.

Brother Amartey empties his resentment against these people:

The Lord says, "I have not sent these prophets, yet they ran: I have not spoken to them yet they prophesied." (Jeremiah 23:21). They prophesy lies in God's name, but God did not send them, command them nor speak to them. They claim to be 'men of God', 'apostles', 'pastors', 'prophets', 'bishops', 'archbishops', and what-not, but they lie! They are ordinary criminals

\footnotetext{
${ }^{19}$ Idem.

${ }^{20}$ Brother Amartey In The Menace Of False Prophets And Pastors In Africa
} 
parading as "men of God" and deceiving the gullible who don't know their Bible and have no discernment.

After having seen the opportunity to make fast and easy money as he wished before, Raja Hey quit working for Preacherman and started his own services away from central Accra to the outskirts with the same modus operandi: markets women and electrifying prayers. Unfortunately, his earnings were not much as that of his "master" Preacherman in Rawlings Park.

In the same vein with Brother Amartey, Caroline Fifamè Bodjrenou in her article "Christianity and Africa's underdevelopment in Swallow, News from Home (Sefi Atta), Not Without Flowers (Amma Darko), Purple Hibiscus and The Thing Around Your Neck (Chimamanda Ngozi Adichie)" states:

This is clear evidence that such pastors not only lack a solid theological training but they are also in quest for money. An evidence of this can be seen in these pastors' interpretation of mental illness in Not Without Flowers where some prophets create a camp called WCS -We Conquer Satan. In their opinion, this disease means possession by evil spirits. ${ }^{21}$

People do believe these so-called "men of God because driven by poverty and their hard will to overcome it and "the prophecy was cooked, the way Ghanaians loved miracles." Furthermore, most African "Christians take their Bible seriously as the be-all in terms of deciding what they should do as Christians, if not in their actual daily lives then at least in public discussions. Biblical examples and injunctions are therefore actively sought to justify and rationalize what to do, how to do it, when to do it and why to do it."

The above passage gives details about the strategy of these new prophets. Further, that of below shows that these fake prophets like Zechariah Abednego in Not Without Flowers (2007) and Jeroboam in The Trials of Brother Jero (1964) have no theological and spiritual trainings, then play with people's faith and beliefs by taking advantage of situations. For instance, Not Without Flowers some people having noticed the quite interesting progress from Raja Hey (a mere dog chain seller) to Abednego (a seer, a prophet), decided to hire him to go to Harvest FM to meet Sylv Po, the presenter of 'Good Morning Ghana' :

He saw the prospect of the kind of opportunity he had been waiting for. This wasn't like the fantasies he had toyed with after the role he had played to get the woman out of her marital home that weekend with her husband's blessing. This plan of his was pretending to be Prophet Abednego. He was Prophet, who was taking advantage of a role he played to further expand his horizon. He would hurt no one. The plan was perfect (Darko, 244).

Regrettably, two weeks after he had been to Harvest FM, he had not heard any comment on his coming and his mysterious disappearance on the radio. To achieve his new plan, he needed a rival radio and a new presenter to convince. He then decided to go to Bright FM to disclose his true false prophecy. Darko goes on:

He placed a call to the station and left a brief and mysterious message. "My name is Prophet Abednego. I prophesised and made a prediction about one of a group of four women of an organization here in Accra. My prophecy has come true". Ask Sylv Po of Harvest FM about it. I will be in touch." When an organization of four women was mentioned in relation to Harvest FM, everyone knew it was MUTE. (Darko, 139-140)

To reach his money-seeking purpose, "Prophet Abednego" lied and persisted by claiming to have been sent "on the orders of the Almighty God Himself. The whole high and mighty He", to deliver a message concerning a man (Agya Ntifor) in a village having an affliction on his leg through Sylv Po's radio.

The more people believe, the more they want to show their gratitude. For example a woman gave her brother's uncompleted building to Prophet Abednego because of her desperate search for visa would find solution by midnight prayers after a long period of fasting. Believing that Raja Hey, our public dog chain seller and hired Prophet, is a strong and powerful man of God, she accepted every order and

\footnotetext{
${ }^{21}$ Ainamon A., Bodjrènou C. (2014) Christianity and Africa's underdevelopment in Swallow, News from Home (Sefi Atta), Not Without Flowers (Amma Darko), Purple Hibiscus and The Thing Around Your Neck (Chimamanda Ngozi Adichie) Numéro 2, Revue du CAMES / Lettres, Langues et linguistique., p26-35
} 
little request coming from him and even the suspicious one. Darko leads the reader there to overhear the phone call of the overwhelmingly excited woman with her brother who, like me, does not believe:

"Oh Bro," she sang, "the way this Prophet Abednego is going about things, I swear Bro, my visa will go through this time. It will go through smoothly like okro down the throat. Do you know how long he fasted? Two weeks Bro. Two whole weeks. And dry oh! Dry fasting. No food, no water. Now it's like the final stages..." The special prayers. He has different special prayers. Special prayers for fertility; special prayers for prosperity and special for visa. And with the visa, there are extra special prayers for American, British and German visas."He is a man of God oh! You wait, as soon as I send the candles for the final prayers, you will begin to see a manifestation of his prayers." "Oh, just a few candles for the final prayers. Twelve black, six red and six yellow. Then the holy bath." "Bath Bro. Sunday midnight, he will go with me to the beach and bath me in the sea. It is called cleansing. (Darko, 360-1)

Raja Hey gives a very precise type of the woman's underpants (G-string) to wear at midnight to come to a beach to undergo that "holy bath", "spiritual bath". I happen to understand the reason why gossips nurture that these new prophets "destroy marriages, families, and even faith to God". In Slaves who love their chains shall remain in bondage, Dr D. K. Olukoya narrates:

An incident took place some time ago which revealed the deceit behind false prophecy. A lady was so hungry that she collapsed during a church service. It happened to be a white garment church. The lady began to roll on the ground, moaning and asking for food. A so-called prophetess at the service started giving false prophecies instead of fetching some food for a hungry person. She prophesy saying, "woman, you are rolling on the ground because 20 witches have decided to kill you. You must buy some candles, oranges, and banana, and bring some cash if you want us to avert death. Thus said the Lord. The poor woman said what the prophetess was saying. What she needed was food. Her hunger had nothing to do with witches ${ }^{22}$.

Currently, Africa has a big number of self-made, fake prophets raking in billions from folk who believe that miracles can improve their lives, not actually ruin them. In greediness and in search for overnight success and miracles, people forget that Prophets we read about in the Holy Bible did not lie about a coming event or foretelling because they are accurate earthly representations of God. When they blessed someone, they were immediately blessed by God. For example, the blessings given by Moses are as good as blessings given by God because the man of God stands for God, his actions are God's actions. On the contrary, when a man of God cursed, cursed was the person, the animal and the place. For example, in the Gospel of Mark, this happened:

The next day as they were leaving Bethany, Jesus was hungry. Seeing in the distance a fig tree in leaf, he went to find out if it had any fruit. When he reached it, he found nothing but leaves, because it was not the season for figs. Then he said to the tree, "May no one ever eat fruit from you again." And his disciples heard him say it. In the morning, as they went along, they saw the fig tree withered from the roots. Peter remembered and said to Jesus, "Rabbi, look! The fig tree you cursed has withered!"23

To validate the power from ancient prophets, Ezra Chitando writes that this understanding of "man of God" "is equally attested in the Elijah and Elisha narratives. The outstanding nature of Elijah is suggested in insinuations that support the suspicion that where Elijah, life or speech is, Yahwe is never far away." 24

Ezra Chitando continues his explanation "Yahweh, the God of Israel, is always hovering around the 'man of God'. This excerpt suggests the proximity of God with the 'man of God' and creates the impression that Elijah "will stride the earth like some Yahwistic ubermensch, unperturbed by the droughts and distances of earth. He is the prophet who "stands before the Lord." ${ }^{25}$

\footnotetext{
${ }^{22}$ Olukoya, D. K. (1999) Slaves who love their chains shall remain in bondage, $1^{\text {st }}$ edition, Yaba, Lagos, Nigeria.

${ }^{23}$ Gospel of Mark 11: 12-15. (2011). Holy Bible New International Version, copyright @ b by Biblical, Inc, CO 80921-3696.

${ }^{24}$ Ezra Chitando, Masiiwa Ragies Gunda, Joachim Kügler (Eds.) (2013). Prophets, Profits and Bible in Zimbabwe (BiAS 4), 2nd ed., Bamberg: UBP.

${ }^{25}$ Ezra Chitando, Masiiwa Ragies Gunda, Joachim Kügler (Eds.) (2013). Prophets, Profits and Bible in Zimbabwe (BiAS 4), 2nd ed., Bamberg: UBP.
} 
The self-proclaimed prophets in Not Without Flowers are just fake ones and Brother Amartey also writes and advises Christians to look in the direction of Acts of Apostles:

Many of these rogues who claim to be "prophets", "pastors" and "men of God" are not even Christians and don't even know the Bible, but they prey on the ignorance and gullibility of so many people who are desperately trying to find God. Many of them are ordinary sorcerers and wizards who use divination to "prophesy," just like Simon the sorcerer in Acts 8:9-13. Simon was a common magician, an unbeliever, who was not even saved, but the ignorant people saw him as "The Great Power of God," because they were enchanted by his sorceries. Just because someone performs miracles, signs and wonders does not make them genuine.

Like Simon referred to in the above passage, Kofi Poku, alias Raja Hey is of similar character. Anyone who studies the Bible or has read it thoroughly would see that the emergence of many fake prophets, pastors and men of God in the world today is nothing but a fulfilment of prophecy. It is one of the signs of the end-times. Christians know that Jesus said," For there shall arise false Christs or false messiahs, and false prophets and shall show great signs and wonders and shall deceive many " The apostles also warned of the coming of "many false apostles, prophets, pastors and antichrists".

These things must be fulfilled because, in the Christians point of view, the word of God is true and must surely come to pass. So when one sees false prophets and pastors and so-called men of God, one should view them as the charlatans and give no regard or respect to them. Certainly, there are true men of God, but it seems that those in contemporary Africa are entertainers, humorists; they do not talk to God does not even talk or were they sent by God. They are in the ministry to acquire money, fame, possessions and cheap sex. They use the name of the Lord to lure in and deceive gullible women and men whether they are married or single; for example market women in search for sale, sex, miracles or visas for Europe, Asia and America.

To cap it all, Mr Kofi Poku alias Raja Hey, is not what he is claiming to be, "man of God and a Prophet". He is a mere liar and a go-getter who takes advantage of situation. He has been sent by Kweku's family to revenge their father suicide because of Aggie, one of MUTE's workers. Additionally, men like Kofi Poku are led by hunger and poverty to take such shameful ways. They think that they have no other way out of their prevailing situation. Then, they jump legs and hands tied into the river of 'opportunism'.

\section{CONSEQUenCES ON AFrica}

As I have stated in my introduction, the merit of Amma Darko is her ringing the alarm and denouncing the phenomenon of fake prophets in her novel Not Without Flowers (2007). However, the social plight of false prophets and pastors is not peculiar to Ghana alone, but also prevails all over the African continent and in America. Many fake prophets, pastors, and men of God (many Kofi Poku, Raja Hey or Zechariah Abednego or Preacherman) have infiltrated the church of Jesus Christ and are causing a great deal of havoc, destroying souls, families, marriages, businesses, and worse of all, faith in God. But biblically, their day of reckoning has come. For in the Gospel John, Jesus Christ declares: "But an hour is coming, and now is, when the true worshipers will worship the Father in spirit and truth; for such people the Father seeks to be His worshipers. God is spirit, and those who worship Him must worship in spirit and truth. ${ }^{26 "}$ A true hour has come and many of them will be exposed and are even being exposed, unless they repent they would surely face swift destruction.

On the contrary, Joseph Yakubu sees nothing fearful, dishonest and shameful in the growing of churches and prophets in Africa. According to him, these people are just expressing their talents in the biblical way of speaking (Matthew 25: 14-30). To Joseph Yakubu, religions are very important to development. Religious attitudes profile our fight for a better future for ourselves and our progenies. He justifies:

Sustainability is becoming a common theme in African Churches today. Less than twenty five years ago, we were taught not to worry about tomorrow, because tomorrow will take care of itself, and to learn from the birds of the air, who have no storage yet they survive (Matthew 6:34). Our preachers tended to only espouse the literal meaning of this scripture, and by

${ }^{26}$ Gospel of John $4: 23$. (2011). Holy Bible New International Version, copyright $\odot$ by Biblical, Inc, CO 80921-3696. 
implication, suggested that those who talk about sustainability were unnecessarily worrying about tomorrow. These preachers were honestly speaking about God's providence without elaborating the nuanced meaning of 'worry'. There is no doubt that this understanding of the scripture was very popular among our people because we live on a continent where half or more of the population lives in poverty, and we have learned to see every day, every meal and every sunrise and sunset as a celebration. ${ }^{27}$

In the same vein, Joseph Ogbonnaya in Religion and Sustainable Development in Africa: The case of Nigeria writes:

Religion can be involved in influencing the progress to a better world. In view of its innumerable adherents and its common belief in the dignity of the human person under God, religion is committed to the promotion of the human good so as to provide basic human needs, guarantee protection of human rights and promote integral development of the globe. Thus, neglecting religion, the source of normative meaning that grounds the architecture of infrastructural and superstructural institutions of society, is misunderstanding the world process as a whole for religious people. ${ }^{28}$

To interpret what James D. Wolfensohn former President of the World Bank said about religions and development, one is quite sure that religions play very important parts in people's socialization. He foresaw the need for closer collaboration of the World Bank and other development institutions with religion and remarked that religion is nothing personal but collective. Then religious faith of people helps shape their view of development and their life in general. However, what James D. Wolfensohm forgot is that when a nation mishandles the implication of religion in development it can creates interreligious wars. In Africa, multiple cases are there to be cited as disastrous examples. Latent interreligious clashes are still feared in some West African countries. Recently, its mishandling enflamed Mali and Nigeria is still crying its daily slaughtered children.

On the opposite of James D. Wolfensohm, the journalist Gideon Thuranira quoted by J. Lee Gradyin Fire in my Bones: 5 ways the gospel of prosperity is hurting Africa, calls fake religious men "churchpreneurs" 29 . He puts in the magazine that "They plant churches not because they have a burden to reach lost souls but because they see dollar signs when they fill an auditorium with chairs. A selfish message produces big headed opportunists who need position, applause and plenty of perks to keep them happy. The most successful prosperity preacher is the most dangerous because he can convince a crowd that Jesus died to give you and me a Lexus" or a class S Mercedes. These "new prophets' all drive first class and glittering cars and live in beautiful buildings and send their children in known American or European universities and then leave their followers in poverty, misery and permanent suffering, prosperity being prepared for them in heaven.

There are characteristics of Kofi Poku, alias Prophet Zechariah Abednego whose mentor character which is his mentor "the Preacherman" also possesses. Nevertheless God's people must know that the prosperity message is an imitation of the gospel because it leaves no room for brokenness and suffering. Prosperity preachers like Zechariah Abednego promise instant results and overnight success, instant visa gaining through electrifying prayers; if you don't get your breakthrough, your miracle, it's because you didn't give enough money in the offering basket. Here again emerges the second generation or era colonization of Africans by their African brothers and sisters. Christianity, priesthood and pastor-hood have become the very breeding and incubation grounds fertilizing the ecological emergence of all cankers. Those new colonizers do not only take away the material wealth and resources of their followers. They rather add to God's power propounded through gospel other more immediate and instantaneous evil and devilish powers taken from the sea and by virtue of which they can command and get immediate obedience from everything and human beings. Some of those newly revealed holy men, who still have their headquarters in Great Britain or America, must deflower virgin followers every month and have sex with spiritual being coming from the sea in order to invigorate their power of gathering more followers, getting more money from the latters and

\footnotetext{
${ }^{27}$ Yakubu, Joseph. (2011). Faith and Sustainable Development: An African Christian Perspective.

${ }^{28}$ Ogbonnaya J. (2012) Religion and Sustainable Development in Africa: The case of Nigeria. Marquette University e-Publications@ Marquette. p 1-23

${ }^{29}$ J. Lee Grady. (2013). Fire in my Bones: 5 ways the gospel of prosperity is hurting Africa (Charisma Magazine).
} 
performing striking miracles. As a matter of fact, those new colonizers of Africa orient their impoverishing arrow on the poor African population who continue to bear the heavy brunt left on the trail of colonization perpetrated by Europeans. In this endeavour, you can see some young men and women walking, carrying bags on their shoulders all day long like errant boys along the street, pretending to be preaching the gospel and teaching people what they themselves do not know, instead of working. The Holy Bible is henceforth overused. Even criminals, armed robbers and cyber bullies make use of it, abrogating to themselves the denomination of prophets, just for achieving their dirty purposes. That is the ins and outs of the new generation of fake and commercial prophets, priests and pastors invading and congregating Africa today. Apart from the poor followers, their other sources of wealth are the ruling powers parties and authorities. They do their utmost to cause the ruling authorities to adopt them as spiritual pastors. As such they can influence and hostage-take any political appointments, becoming thereby public contracts bidders-winners, and public services suppliers. The so-called Holy men or prophets tap into and capitalize on all means nowadays to raise money and wealth irrespective of the thinking in the public opinion.

For example, after having failed to convince Sylv Po to let him (Prophet Zechariah Abednego) convey the message God hasn't told him and having already calculated what to say during the interview, he rides back to a rival radio (Bright FM). Darko divulges the very moment:

Raja didn't feel comfortable about the way the questioning was going. He jumped into what he wanted the listeners to hear. "God has worked one miracle through me. I am convinced that it is the first of many miracles to come! He launched his pitch, "In fact, I consider the many people who have turned in and are listening to me are my followers. All I need is to find a place where my followers and I will congregate. So I am reaching out at this moment to anyone out there who at this very instant is feeling something inside to help. The person is out there and has ready premises I can use as the holy ground to gather my followers. (Darko,

At this point, the message is to reach auditors' heart to ask for plot of land, place to congregate the followers he did not have yet and then to reach his dream "lie to people and get their money and properties" through his gospel of prosperity. The result was instant the next day:

A woman walked personally to Bright FM to offer Prophet Abednego the use of an uncompleted building belonging to her brother who was resident in Germany. The woman smiled shyly. "Actually I also have one humble request for the powerful prophet!" she confessed. "You see, my brother, the one whose uncompleted building I am offering to the prophet, has been trying for years to get me to join him in Hamburg. The money he has wasted eh! No visa. Reject. Ei! "But I think that this Prophet Abednego is so strong and powerful. I am sure he will be able to tie up the feet of that witch so that the present ongoing arrangement will go through successfully for me to get my visa for Germany."

Subsequently, people's love of miracles and overnight success, leads them to listen to the message of this fortune hunter, Kofi Poku. They believed him as strong and powerful man of God. Even Teacher, an educated woman, was embarked to convey that false information. The message delivery of the socalled Prophet is meant to convince Ntifor, his two wives and his children that the swelling is a spiritual issue and so neither the seasoned herbalist nor hospital medicine could heal it, but that Ntifor has to be immediately baptised and "receive Holy Communion". Then Ntifor being accepted as a member of the Prophet's follower, he has to repent from his past sins, one of which is the polygamy in which he dwells with Mena Kakraba and Mena Penyin.

In The Trial of Brother Jero (1964), the interest of Soyinka is the use of satire as a potent weapon to mock political problems, leadership, mediocrity vice-versa religious hypocrisy, moral decadence, exploitation and egoistic tendencies of the people trusted with the mandate of the masses ${ }^{30}$. The concern of this research study is to enumerate the relevance of satire for the correction of sociopolitical and religious ills of contemporary Ghanaian Society and Darko uses with dexterity to convey the message.

At last, Agya Ntifor, like Ma, Randa's mother, was admitted to hospital to receive medicine against his swollen leg. There came the doctor with the diagnosis: sat up and replaced his pen inside his coat

\footnotetext{
${ }^{30}$ Soyinka W (1964). The Trials of Brother Jero. In The Jero Plays, Ibadan: Spectrum Bks. Ltd, pp.7-45.
} 
pocket. Then he cleared his throat and asked simply, "Have you ever heard of the skin disease called Buruli ulcer?" The disease affects people who lived near rivers and stagnant waters and affect mostly women and children under fifteen years of age. Old men like Ntifor are not usually attacked.

Basically, God does not operate from the sky to rescue human beings from their problems, oppression, conflicts, violence and injustice. He acts through Prophets, men of God, however He warns his fellow believers against fake prophets, the ravenous, opportunists, prevailing in Africa. After slave trade, colonisation, poverty, and fake independence, Africa is now enchained by the plight of "fake prophets". Here fake independence stands for African countries' economic dependence to International Monetary Fund and World Bank systems. Each year, African leaders must go to Europe or America for conferences related to the amount of money for their annual budget and other expenses. They are arms and legs bound by chains hold by these monetary decision-makers. They say Africa is free only to be chained by poverty, illiteracy, tribal and interreligious wars.

\section{CONCLUSION}

Amma Darko's Not Without Flowers gives the reader a very broad insight about the prevailing plight of fake prophets who have, in perpetuation of colonialism, taken over from the western missionaries to propound their fake gospel of prosperity in contemporary Africa. This shows the social, moral and spiritual deliquescence in African post-colonial ear. Though Darko recognizes like every panAfricanist, colonization and its disadvantages, she seems to be convinced that African traditional religions and Christianity are not bad at all while handled with care and delicacy. In "Rethinking African theology: exploring the God who liberates":Jean-Marc Ela suggests that "Theologians should make efforts to show that God's revelation through Jesus Christ finds its full meaning in Africa when the church brings the Gospel as a message of liberation" if not what is going on down there is a "nonsense" $"$.

A nation needs religion to shape its attitudes towards socio-economic issues. African traditional religions and Christianity play then important roles in communities. Darko however recognizes that, like the Holy Scriptures warns, one should not be fooled like that woman who gave her brother's property and blindly believed that just a "holy bath at beach in midnight with a G-string" could allow her to gain a visa to Europe. Darko wants the Africans to be eyes open and to remember that when our forefathers closed them they lost their green and fertile pastures and lands, to retake Mzee Jomo Kenyatta's maxim. It is sad that African Governments haven't bothered to probe such 'scriptural abracadabra,' which defies logic. Is it because Governments, too, have similar burdens in this diabolical game of duping paupers?

A society whose cultural values have been eroded also loses its identity because culture defines who we are, how other people see us and how we are able to relate to our natural and social environments in order to ensure survival in a social environment that has been bedeviled by unbridled contestation for political and economic supremacy.

After more than fifty years of independence, Christianity should not be a handicap to African faith and development, simply due to its being part and parcel to colonization. Educated and awakened men and women like Sylv Po, Muff, Dina, Vickie, Aggie and the man in Germany know that the synthesis is very important. In her fiction, Darko therefore reaffirms an already known position of a theology that seeks to provide food for the hungry, shelters the homeless, liberates the oppressed and which restores full dignity to a human being created in the image of God. So, when Africans happen to meet Raja Heys or Preachermen or someone similar on their way to developing faith in God all that they have to do is to remember what Darko suggests to the man in Germany: "get that prophet (now written with a small p) of yours out of my house."This is Darko's way to terminate the prevailing social plight.

\section{REFERENCES}

[1] Ainamon A., Bodjrènou C. (2014) Christianity and Africa's underdevelopment in Swallow, News from Home (Sefi Atta), Not Without Flowers (Amma Darko), Purple Hibiscus and The Thing Around Your Neck (Chimamanda Ngozi Adichie) Numéro 2, Revue du CAMES / Lettres, Langues et Linguistique., p26-35

\footnotetext{
${ }^{31}$ Ela, Jean-Marc. (2003). "Rethinking African theology: exploring the God who liberates". Paris: Karthala.
} 
[2] Bediako, K. (1999). Theology and Identity: Theology and Identity: Impact of Culture upon Christian Thought in the Second Century and in Modern Africa. Regnum Books, 507pp, ISBN: 187034510X.

[3] Conrad, J. (1899). Heart of Darkness. (Eds.) London: Harper Collins Press.

[4] Darko, A. (2007). Not Without Flowers. Accra, Sub-Saharan Publisher.

[5] Ezra Chitando, Masiiwa Ragies Gunda, Joachim Kügler (Eds.) (2013). Prophets, Profits and Bible in Zimbabwe (BiAS 4), 2nd ed., Bamberg: UBP.

[6] Holy Bible New International Version (2011) copyright @ by Biblical, Inc, CO 80921-3696.

[7] Grady, J. Lee (2013). Fire in my Bones: 5 ways the gospel of prosperity is hurting Africa (Charisma Magazine).

[8] Ela, Jean-Marc (2003). "Rethinking African theology: exploring the God who liberates". Paris: Karthala.

[9] Koponen, Juhani (1993). The Partition of Africa: A Scramble for a Mirage? Ed, Nordic Journal of African Studies 2(1): 117-135.

[10] Okuyade, Ogaga. (2011) Women and Evangelical merchandising in the Nigerian filmic enterprise. Kemanusiaan Vol. 18, No 1. (2011), 1-14. Penerbit Universiti Malaysia.

[11] Okuyade, O. (2006). Selling god with women: The world and women in the Nigerian Filmic Enterprise, Uyo Journal of Humanities, 11: 1-20.

[12] Ogbonnaya, J. (2012) Religion and Sustainable Development in Africa: The case of Nigeria. Marquette University e-Publications@Marquette.p 1-23

[13] Olukoya, D. K. (1999) Slaves who love their chains shall remain in bondage, $1^{\text {st }}$ edition, Yaba, Lagos, Nigeria.

[14] Maffly-Kipp, Laurie F. (2001). An Introduction to the Church in the Southern Black Community. Illinois Press.

[15] Mutingwende, Byron //nehandaradio.com/2014/05/17/battle-supremacy-among-prophets-rages/

[16] Meredith, Martin (1964) Reported in. The Fate of Africa, p.266.

[17] Soyinka W. (1964). The Trials of Brother Jero. In The Jero Plays, Ibadan: Spectrum Bks. Ltd, pp.7-45.

[18] The New Testament, (2007) Good News Translation, published by United Bible Societies, Nairobi, Kenya.

[19] The King James Bible, (2000) copyright (C) Doctor of Theology Robert A. Couric 2000, 2003.

[20] Yakubu, Joseph (2011) Faith and Sustainable Development: An African Christian Perspective.

[21] Yankah, Kwesi (2007) Foreword in Not Without Flowers. Accra, Sub Saharan Publisher.

Citation: Koumagnon A. Djossou Agboadannon, Ashani Michel Dossoumou. “ Fake Prophets and Evangile for Sale in Amma Darko's Not without Flowers" International Journal on Studies in English Language and Literature (IJSELL), vol 6, no. 6, 2018, pp. 15-29. doi:http://dx.doi.org/10.20431/2347-3134.0606003.

Copyright: (C) 2018 Authors. This is an open-access article distributed under the terms of the Creative Commons Attribution License, which permits unrestricted use, distribution, and reproduction in any medium, provided the original author and source are credited. 